\title{
ANALYSIS OF SPRING BARLEY INTRASPECIFIC POLYMORPHISM IN CONNECTION WITH TOLERANCE TO LEAD
}

\section{A.V. DIKAREV, V.G. DIKAREV, N.S. DIKAREVA, S.A. GERAS'KIN}

All-Russian Research Institute of Agricultural Radiology and Agroecology, Russian Academy of Agricultural Sciences, 109 km, Kievskoe sh., Obninsk, Kaluzhskaya Province, 249032 Russia, 109 KM, e-mail dikarev.vlad@yan-dex.ru, stgeraskin@gmail.com

Received September 10, 2012

\section{Abstract}

Under technogenic pollution, phytotoxicity of heavy metals (HM) becomes a factor limiting yield and quality of crop production. In breeding, an intraspecific polymorphism of resistance to technogenic factors should be estimated with the analysis of its formation and maintenance. Using spring barley (Hordeum vulgare L.) Zazerskii 85, Gorinskii and Chelyabinskii 1 varieties, we studied the influence of different $\mathrm{Pb}\left(\mathrm{NO}_{3}\right)_{2}$ concentrations $(1.0 ; 1.5 ; 2.0 ; 2.5 ; 3.0 ; 3.5$; $4.0 ; 4.5 ; 5.0 \mathrm{mg} / \mathrm{ml})$ on the growth of roots and offsprings in seedlings. Then, a testing concentration of $\mathrm{Pb}\left(\mathrm{NO}_{3}\right)_{2}$ found out was applied to investigate an intraspecific polymorphism of barley plant tolerance to the toxicant. The cultivars from the VIR World Collection (N.I. Vavilov Research Institute of Plant Industry, St. Petersburg) were tested using seeds reproduced in 2008, 2009 and 2010 (36, 100 and 24 varieties, respectively). The varieties were divided into classes according to Sturges' rule. The lead sensitive and lead tolerant forms were separated basing on a depression coefficient. According to root growth, the highest tolerance was observed in the Gorinskii variety, and the Zazerskii 85 variety was the most sensitive. The influence of lead resulted in a shift of distribution of 100 cultivars to less offspring length, but according to Kolmogorov-Smirnov criterion there were no significant differences between the empiric distributions $\left(\mathrm{D}=0.17<\mathrm{D}_{0.05}=0.26\right)$. The tolerance to lead in varieties from the first and the last classes differed 2.0-4.5 times (i.e. from total suppression to growth stimulation). According to the length of the offsprings from the seeds reproduced in 2008 and 2010, there were no reliable differences from control $\left(\mathrm{D}=0.167<\mathrm{D}_{0.05}=0.434\right.$ and $\mathrm{D}=0.125<\mathrm{D}_{0.05}=0.531$, respectively). A statistically unreliable stimulation of the seed germination also occurred $\left(D=0.306<D_{0.05}=0.320\right.$ and $\mathrm{D}=0.208<\mathrm{D}_{0.05}=0.392$, respectively), probably because of less number of the tested samples. Lead caused multiple changes of the root morphology. Basing on morphological parameters, the varieties with a contrast tolerance to lead was revealed. Possible mechanisms of polymorphic tolerance of barley cultivars and other plants to HM are discussed. These data can be used under creation of agricultural plants tolerant to heavy metals.

Keywords: lead, barley, intraspecific polymorphism, contrast cultivars.

Technogenic pollutions destruct both natural and agricultural ecosystems. The polluted territory covers about 18 million hectares, or $1 \%$ of the total area of the Russian Federation. The area of heavy metal pollution of soil is 3.6 million ha. More than 1 million hectares of agricultural land are contaminated with high toxic elements (I hazard class), 2.3 million hectares with toxic elements (II hazard class) (1). Therefore, the HM phytotoxicity becomes one of the factors limiting the yield and quality in crop production.

For efficient agriculture, it is essential to use plant varieties tolerant to technogenic pollution provided high quality of crop production $(2,3)$. Thus, an estimation of intraspecific polymorphism of the main crops with respect to their tolerance to technogenic factors and the elucidation of how this polymorphism is generated and maintained are extremely important. Barley is a valuable food grain and forage crops. There are enough scholarly publications on different aspects of HM effects in barley. For instance, cytogenetic violations $(4,5)$, antioxidant activity (6), apoptosis (7), physiological processes (8), etc., are being studied. However, the mechanisms of barley tolerance to HM, in particular lead as a main pollutant of aquatic and terrestrial ecosystems, still remain unclear (9-13). 
In this paper there are summarized the data on intraspecific polymorphism analysis of lead tolerance in spring barley.

Technique. In the preliminary examinations, 100 seeds of barley (Hordeum vulgare $\mathrm{L}$.) Zazerskii 85 variety were exposed to $\mathrm{Pb}\left(\mathrm{NO}_{3}\right)_{2}$ solutions (1.0, 2.0, 3.0, 4.0, 5.0, 6.0, 7.0, 8.0 and $9.0 \mathrm{mg} / \mathrm{ml}$ ). In extra experiment the seeds of Gorinslii and Chelyabinskii 1 variety were treated with $\mathrm{Pb}\left(\mathrm{NO}_{3}\right)_{2}$ at $1.0,1.5$, $2.0,2.5,3.0,3.5,4.0,4.5$ and $5.0 \mathrm{mg} / \mathrm{ml}$ to verify the results obtained. For each variety $\mathrm{EC}_{50}$ was assessed to find out the $\mathrm{HM}$ concentration depressing $50 \%$ growth of roots or shoots. This parameter was used to compare lead tolerance in the varieties.

For further experiments, the seeds reproduced in 2009 were tested in 100 barley varieties from the VIR World Collection (N.I. Vavilov Research Institute of Plant Industry, St. Petersburg). Additionally the seeds of 36 and 24 varieties reproduced in 2008 and 2010, respectively, were used. For each variant the samples, i.e. 100 control seeds and 100 tested seeds, were germinated at $20{ }^{\circ} \mathrm{C}$ for 7 days using rolled paper (14). Effect of $\mathrm{Pb}\left(\mathrm{NO}_{3}\right)_{2} 1.5 \mathrm{mg} / \mathrm{ml}$ concentration was compared to deionized water as a control. We determined the parameters of germination, shoot and root length, the percent of strong seedlings with embryonic leaf of more that half the lengths of coleoptile, and morphological violations were examined. In case the embryonic leaf was less than that half the length of coleoptile or the roots were less than $5 \mathrm{~mm}$ in length and had no specific triple fork, the seedlings were considered weak.

To analyze barley tolerance to lead, the varieties were divided into classes according to Sturges' rule (see 15):

$$
\begin{aligned}
& k=1+3,3 \lg n, \\
& i=\frac{X_{\max }-X_{\min },}{k}
\end{aligned}
$$

with $n$ as sample number, $k$ as class number, $X_{\max / \min }$ as maximal and minimal parameter, $i$ as the width of the class intervals. Class number increased as variety tolerance increased.

Lead sensitive and lead tolerant varieties were chosen with respect to depression coefficient $(D C)$, calculated as:

$$
D C=\frac{M V_{c}-M V_{d}}{M V_{c}} \times 100 \% \%,
$$

with $M V_{c}$ as a parameter value in control and $M V_{d}$ as that at $1.5 \mathrm{mg} / \mathrm{ml}$ lead concentration.

$D C$ was calculated for the length of shoot and root, and for the percent of strong and germinated seedlings, then summarizing the indices. The seedlings were considered tolerant or sensitive if the sum was less than 50 of more than 100 , respectively. In case the variety was classified as sensitive for 2 years, but the aforementioned sum for the year 3 was $50-60$, so approaching a variation rage of the opposite group, or the variety was classified as tolerant for 2 years, but the aforementioned sum for the year 3 was $90-100$, these varieties were discarded.

To compare results, the Kolmogorov-Smirnov test $(16,17)$ and MannWhitney test (18) were used. Calculations were carried out by means of Statistica v. 10.0 and MS Excel 2003.

Results. Root length decreased sharply (Fig. 1, A) at minimal lead nitrate concentration $(1.0 \mathrm{mg} / \mathrm{ml})$. In Zazerskii 85 , Chelyabinskii 1 and Gorinskii varieties the $\mathrm{EC}_{50}$ values were $2.0 \mathrm{mg} / \mathrm{ml}$ (shoots) and $1.0 \mathrm{mg} / \mathrm{ml}$ (roots), $2.5 \mathrm{mg} / \mathrm{ml}$ (shoots) and $1.0 \mathrm{mg} / \mathrm{ml}$ (roots), and $3.5 \mathrm{mg} / \mathrm{ml}$ (shoots) and $1.5 \mathrm{mg} / \mathrm{ml}$ (roots), 
respectively, so Gorinskii variety was the most tolerant, while Zazerskii 85 variety was the most sensitive.

From $4 \mathrm{mg} / \mathrm{ml}$ concentration there was a complete repression of root growth in all variants. However, the length reduction in shoots was much less noticeable (see Fig. 1, B). At $1 \mathrm{mg} / \mathrm{ml}$ lead nitrate there was a reliable stimulation $(\mathrm{p}=0.01)$ of shoot development in Chelyabinskii 1 and Gorinskii varieties. P. Soudek et al. (19) described similar effect of lead to flax. At $2 \mathrm{mg} / \mathrm{ml}$ and more an shoot growth repression was observed. There also are the similar results in V.V. Talanova's et al. (20) report.

Fig. 2 shows the distribution of 100 barley varieties on shoot length and seed germination influenced by $\mathrm{Pb}\left(\mathrm{NO}_{3}\right)_{2}$ at $1.5 \mathrm{mg} / \mathrm{ml}$. The samples are grouped from 1 to $8-9$ classes of the most sensitive and most tolerant samples, respectively.

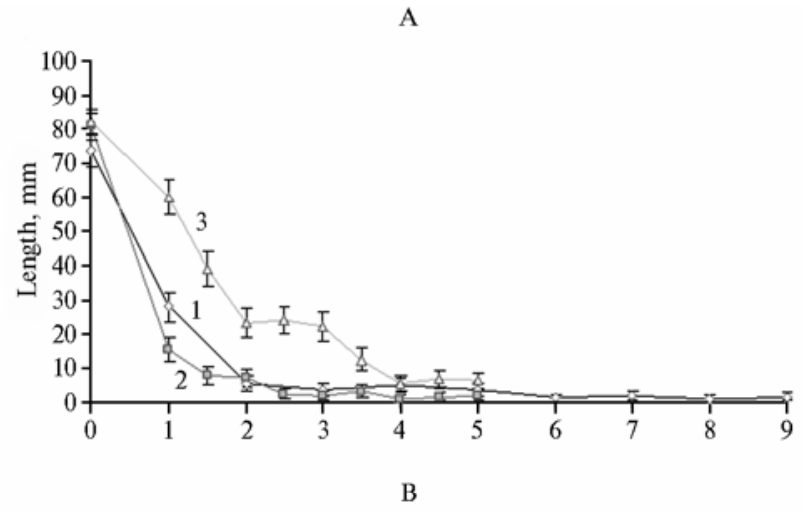

The distributions in control and at the lead nitrate influence were relatively smooth. At lead presence there was a shift to less shoot lengths (see Fig. 2, A), however, the KolmogorovSmirnov test did not show the significance of difference between empirical distributions $\left(\mathrm{D}=0.17<\mathrm{D}_{0.05}=0.26\right.$ ).

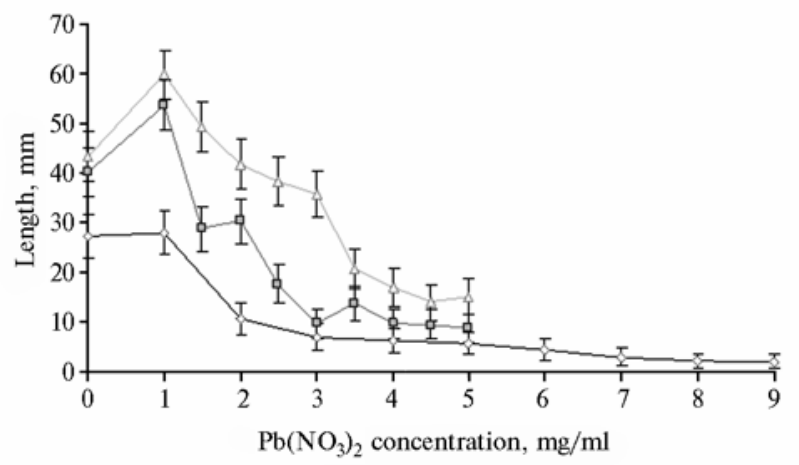

Fig. 1. Root (A) and shoot (B) length in spring barley (Hordeum vulgare $\mathrm{L}$.) varieties as influenced by different $\mathrm{Pb}\left(\mathrm{NO}_{3}\right)_{2}$ concentrations: 1 - Zazerskii 85,2 - Chelyabinskii 1, 3 - Gorinskii. The shoot length curves under lead influence reflect a more even variety distribution between the classes.

Germination curve at lead nitrate stress was right shifted (see Fig. 2, B). Besides, a reliable stimulation was shown for seed germination $\left(\mathrm{D}=0.29>\mathrm{D}_{0.05}=0.26\right)$. Moreover, the varieties in the first and last class differed on lead tolerance 2.04.5 times, from total growth repression to stimulation.
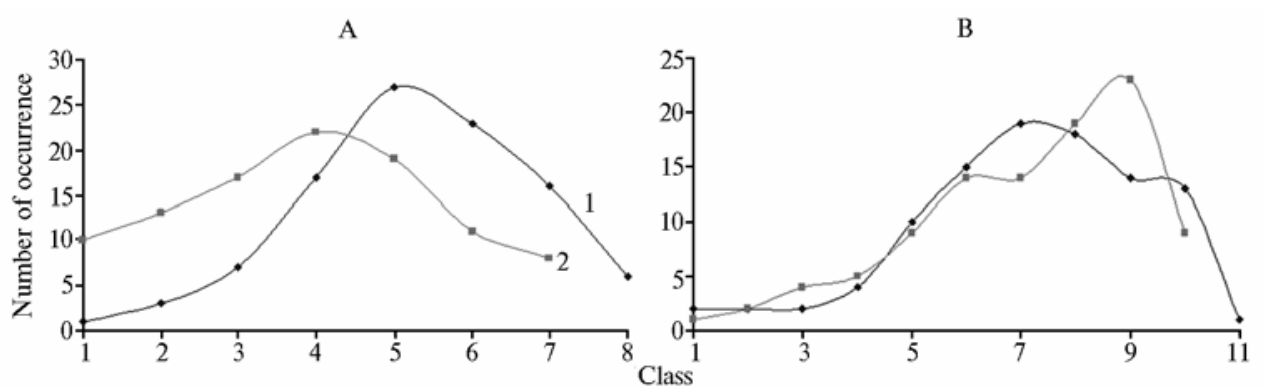

Fig. 2. Spring barley (Hordeum vulgare $\mathrm{L}$.) variety distribution on $\mathrm{Pb}\left(\mathrm{NO}_{3}\right)_{2}$ tolerance with regard to shoot length (A) and seed germination (B) as influenced by $\mathbf{P b}\left(\mathrm{NO}_{3}\right): 1-$ control, $2-\mathrm{Pb}\left(\mathrm{NO}_{3}\right)_{2}$ concentration $1.5 \mathrm{mg} / \mathrm{ml}$ (the seeds reproduced in 2009). 
As to length of the shoots from seeds harvested in 2008 and 2010 (Fig. 3, A, B), no reliable differences from control were found $\left(D=0.167<D_{0.05}=0.434\right.$ and $\mathrm{D}=0.125<\mathrm{D}_{0.05}=0.531$, respectively). Stimulation of seed germination was statistically unreliable $\left(\mathrm{D}=0.306<\mathrm{D}_{0.05}=0.320\right.$ and $\mathrm{D}=0.208<\mathrm{D}_{0.05}=0.392$, respectively) (see Fig. 3, C, D). Unreliable differences from the control values could be due to less number of varieties tested.

A

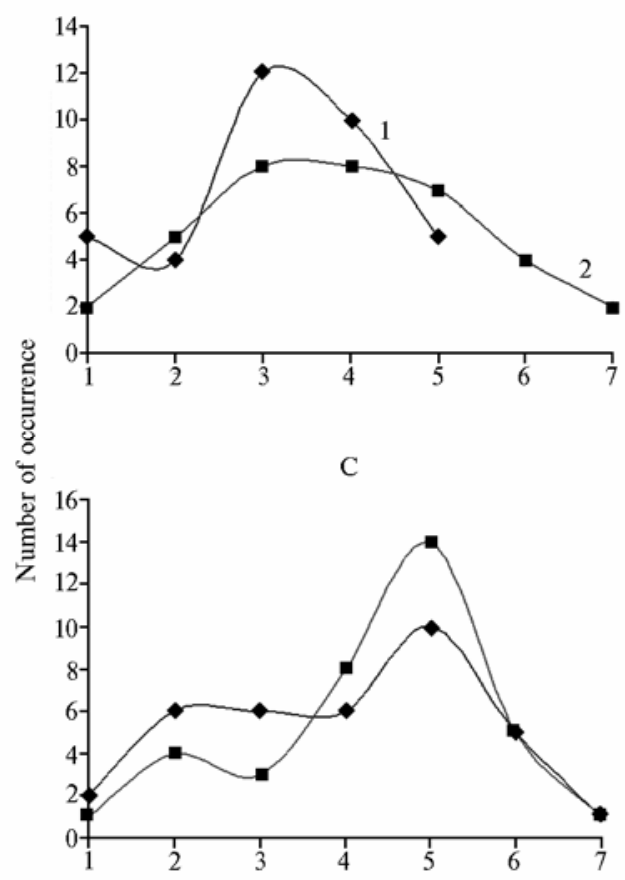

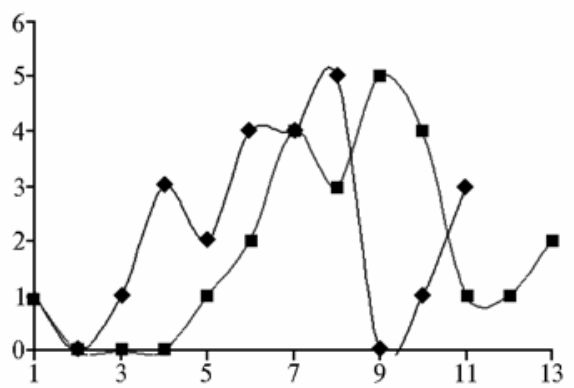

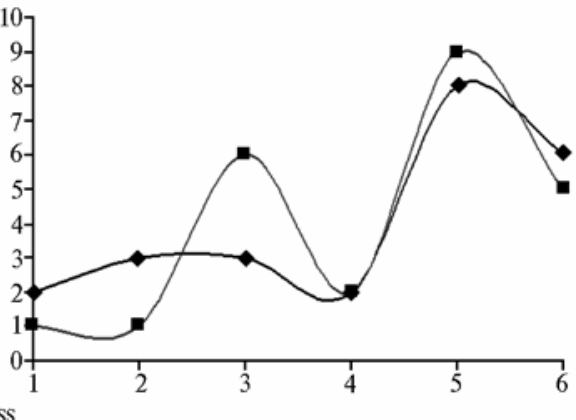

Fig. 3. Spring barley (Hordeum vulgare $\mathrm{L}$.) variety distribution on $\mathrm{Pb}\left(\mathrm{NO}_{3}\right)_{2}$ tolerance with regard to shoot length $(\mathrm{A}, \mathrm{B})$ and seed germination $(\mathrm{C}, \mathrm{D})$ depending on the year of seed reproduction: $\mathrm{A}, \mathrm{C}-$ 2008, B, D - 2010; 1 - control, $2-\mathrm{Pb}\left(\mathrm{NO}_{3}\right)_{2}$ concentration $1.5 \mathrm{mg} / \mathrm{ml}$.

From the obtained date we calculated the depression coefficients $(D C)$ to choose lead sensitive and lead tolerant varieties (Table). The same index was used in other studies to investigate HM tolerance in flax seeds (19) and detect the wheat varieties with contrasting resistance to ionizing radiation (21). In the Table there are listed varieties with the status confirmed at least for 2 years.

Sum of depression coefficients $(D C)$ in the spring barley (Hordeum vulgare L.) varieties with contrasting tolerance to $\mathrm{Pb}\left(\mathrm{NO}_{3}\right)_{2}$ depending on the year of seed reproduction

\begin{tabular}{lccc}
\hline \multicolumn{1}{c}{ Variety and its origin } & 2008 & 2009 & 2010 \\
\hline Vyatskii (Kirovskaya Province) & T o l e r a n t & & $32.4(+)$ \\
Teo (Great Britain) & $25.9(+)$ & 53.2 & $32.4(+)$ \\
Zarya (Kirovskaya Province.) & $35.1(+)$ & $24.6(+)$ & $-34.2(+)$ \\
Donum (Czech Republic) & $15.8(+)$ & $11.9(+)$ & $-35.0(+)$ \\
Simfoniya (Khar'kovskaya Province) & 72.3 & $-78.2(+)$ & $42.9(+)$ \\
Pongo (Sweden) & $21.6(+)$ & 56.3 & 53.2 \\
& $26.3(+)$ & $-9.2(+)$ & 70.6 \\
Melikum 336 (Samarskaya Province) & S e n s i t i v e & $116.0(+)$ & 99.2 \\
Myt' (Ukraine) & $244.0(+)$ & $119.5(+)$ & $113.1(+)$ \\
Jelen (Yugoslavia) & $106.3(+)$ & $114.1(+)$ & $166.3(+)$ \\
NSGL 1 (Yugoslavia) & $105.7(+)$ & $215.9(+)$ & $241.6(+)$ \\
3aвeтный (Rostovskaya Province) & 82.7 & $245.4(+)$ & 89.6
\end{tabular}

Com ments. The varieties with lead tolerance or sensitiveness confirmed for seeds of the relevant year are marked as «+». 

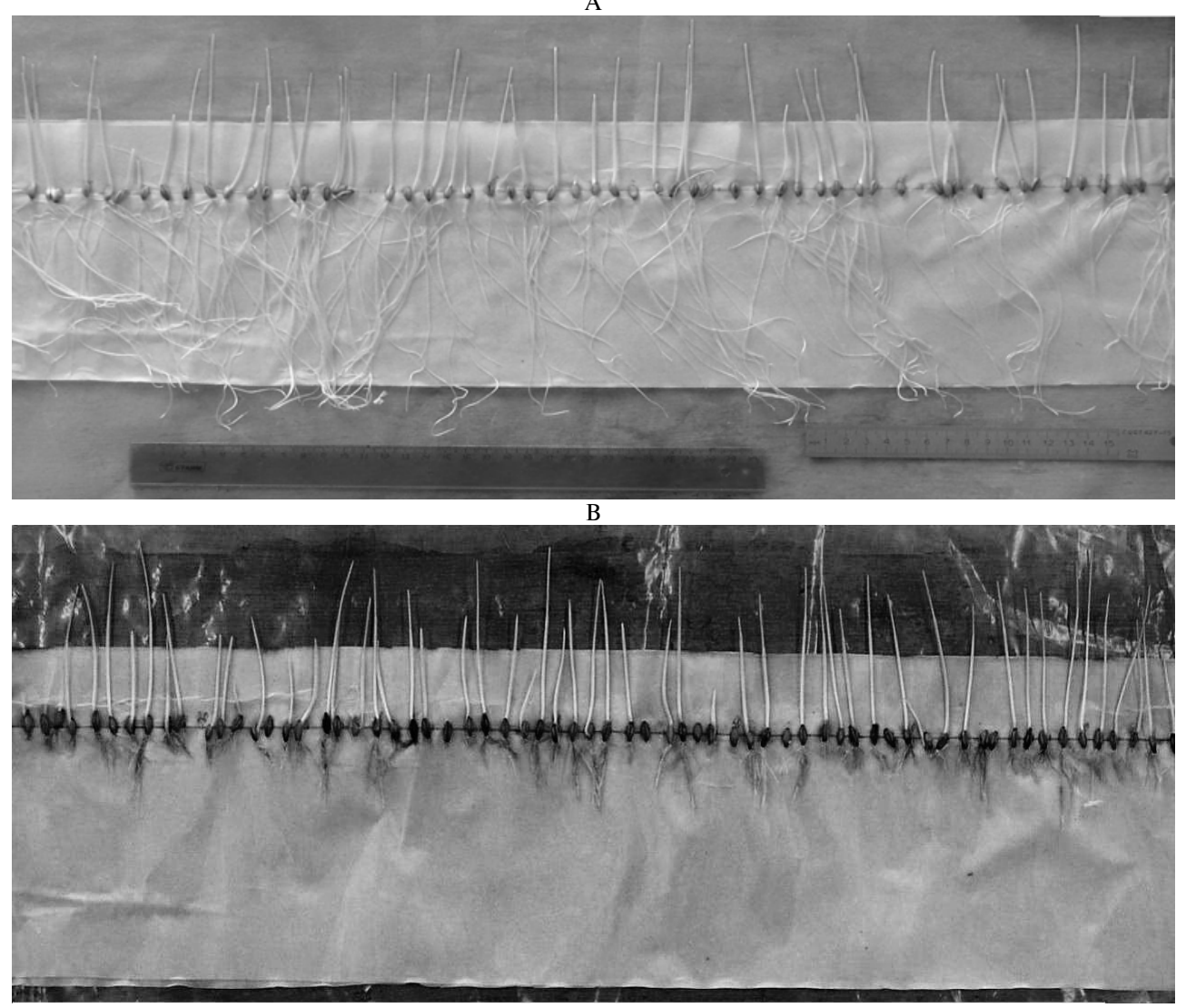

Fig. 4. Changes of root morphology in 7-day old seedlings of spring barley (Hordeum vulgare L.) variety Zavetnii sensitive to $\mathbf{P b}\left(\mathrm{NO}_{3}\right)_{2}$ : $\mathrm{A}-$ control, $\mathrm{B}-\mathrm{Pb}\left(\mathrm{NO}_{3}\right)_{2}$ concentration $1.5 \mathrm{mg} / \mathrm{ml}$.

In addition to growth depression, lead exposure caused numerous changes in root morphology (Fig. 4), such as apex curvature (the violation of geotropism), swelling, induration, discoloration. Similar lead effects were reported by S.V. Murzaeva (8).

There are the basic strategies of plant adaptation to the environment containing redundant concentrations of metals, namely a decrease in their input, activation of the excretion, and metabolic change to minimize the harmful effects. In case the plants accumulate HM at the levels higher than or the same as the external metal concentration, they are referred as accumulators and indicators, respectively (22). Most plants are indicators. Different varieties of the same species can demonstrate different adaptation strategies (23), which are the base for polymorphism on metal tolerance.

At HM absorption from soil, the cation-binding uronic acids from the root mucus are the main barrier (24). There are some more barriers in plants to protect from harmful external substances. The first of them are the cells of the endoderm and stele responsible for the inception of lateral roots, so the excess HM disrupts the development of the root system and decreases the root number. Besides, plasmalemma, due to ion retaining ability, prevents HM involvement into metabolism (25). Our data (see Fig. 1, 4) also show higher sensitiveness to lead in roots.

Stimulation of germination and further growth depression observed herein can result from an increased intracellular concentration of reactive oxygen species due to HM (26), then leading to the activation of antioxidant enzymes. As a result, the germination ability improves (8). Nevertheless, as lead 
concentration in plant increases up to toxic level, the growth repression occurs. In pre-tests at high HM concentrations no stimulated germination was observed.

Plasmalemma is a major HM target in cell. Lead ions change its permeability and ion balance (30), impact the $\mathrm{H}^{+}$-ATФase activity and the lipid composition of membranes (31), probably because of disruption of the lipid synthesis and lipid oxidation by reactive oxygen species generated due to HM. In case lead still got into the cytoplasm, the synthesis of metal binding compounds, the phytochelatins and metallothioneins, is triggered via HM activated synthesis of their precursor, the glutathione. HM ions generate insoluble compounds which are deposited in the vacuoles (27-29).

Lead can indirectly affect the metabolism by binding with $\mathrm{SH}$-groups and active sites of enzymes, thus inhibiting their activity. Such HM repression in plants results in photosynthetic violations (e.g. thylakoid membrane destruction and failures in the Calvin cycle), water stress (e.g. increased cutin synthesis and decreased transpiration), repression of cell division (e.g. DNA crosslinking, violation of cytokinesis because of delayed microtubule assembly), and an inhibition of respiratory enzymes occurs and the mitochondrial membranes are damaged (32). In our experiments, growth repression in barley could result from these processes. The seed germination observed herein has been also observed by other researchers, being firs described for X-rays $(33,34)$.

Therefore, lead has a general toxic effect on plants. In response to lead presence the defense systems are activated, in particular, superoxide dismutase, catalase and peroxidase functions enhance (35), osmolytes (proline) and polyamines (putrescine) are synthesized, the changes occurs in cell wall composition due to callose and suberin depositions (36) as well as in hormonal balance, including ethylene and abscisic acid (37), and the expression of metal binding proteins, the phytochelatins, is triggered (38).

It is shown (39-41), that species, varieties and even populations within a species differ on HM tolerance. Possible causes for this may be (38) the different tolerance of transport and absorption processes, the different intensity of HM binding and deposition into vacuoles, the different rate of ion transport from roots and HM deposition into root tissues, the synthesis of HM-resistant enzyme, the activation of HM excretion from the cell. Basing on these processes, the researchers can differentiate plant varieties and lines on tolerance to $\mathrm{HM}$ (11, 42-45), X-rays (46) and other agents (47-49).

T.V. Zhuikov et al. (44) studied the effect of $\mathrm{HM}(\mathrm{Cd}, \mathrm{Zn}, \mathrm{Pb})$ to dandelion seedlings of two lines grown from seeds that were collected at 8 contaminated sites around the city of Nizhnii Tagil. One of these lines was shown to produce more viable seeds, while the other one produced more tolerant seedlings. Depending on pollution gradient the tolerance in each line changes in different ways. Authors suggest a different strategy of response to pollution, so the first line is targeted to higher seed quality, and in the second one there is higher seed yield resulting in more seedlings which develop faster and form more roots and leaves. Both the lines co-exist in the same cenopopulation.

M.R. Broadley et al. (50) compared the species of angiosperms on their response to different HM. The rate of $\mathrm{HM}$ accumulation was shown to be due to phylogenesis. There are the evidences that specific reactions in plants were formed during the evolution, and they change according to taxonomy.

In general, in all these researches similar results are reported, namely the stress tolerance in plants of the same species can differ significantly, thus allowing selecting forms with a contrasting tolerance. This differentiation results from different detoxication efficacy among the varieties of the same species. Also there 
are publications dedicated to the impact of the pollutant on one species, regardless to its varietal differentiation. P.M. Kopittke et al. (11) investigated the effect of different lead concentration to seedlings of cowpea Vigna inguiculata. These results are consistent with our data, in particular, they revealed morphological violations, especially in roots (bending, thickening, discoloration), and also the lead compound deposits were shown in the root tissues. Effect is enhanced as the concentration increases.

Thus, we have shown the negative effect of high lead concentrations, more than $4 \mathrm{mg} / \mathrm{ml}$, on the morphological parameters of barley seedlings. The roots of seedlings were most sensitive to this agent. There was detected a significant stimulation of germination of seeds in certain varieties under the influence of lead at $1-2 \mathrm{mg} / \mathrm{ml}$ concentration. The spring barley polymorphism according to lead tolerance is described. Based on the morphological parameters of seedlings, the varieties contrasting in lead tolerance are revealed.

\section{REFERENCES}

1. Aleksakhin R.M., Fesenko S.V., Geras'kin S.A. et al. Metodika otsenki ekologicheskikh posledstvii tekhnogennogo zagryazneniya agroekosistem [Estimation of ecological consequences of technogenic pollution in agroecosystems]. Moscow, 2004.

2. Che r $\mathrm{n}$ y k h N.A., E d m on S.A. Agrokhimiya, 2004, 10: 78-85.

3. M in ki n a T.M. Agrokhimiya, 2011, 6: 68-77.

4. Geras'kin S.A., Dikarev V.G., Dikareva N.S., Ud alova A.A. Genetika, 1996, 32(2): 272-278.

5. Gera s'ki n S.A., K i m J.K., D i karev V.G., D ik a re va N.S., O u d a lova A.A. Cytogenetic effects of combined radioactive $\left({ }^{137} \mathrm{Cs}\right)$ and chemical $(\mathrm{Cd}, \mathrm{Pb}$ and $2,4-\mathrm{D}$ herbicide) contamination on spring barley intercalar meristem cells. Mut. Res., 2005, 586: 147-159.

6. Wu F., Zhang G., D o miny P. Four barley genotypes respond differently to cadmium: lipid peroxidation and activities of antioxidant capacity. Environ. Exp. Bot., 2003, 50: 67-78 (doi: 10.1016/S0098-8472(02)00113-2).

7. $\mathrm{Pan}$ J.-W., $\mathrm{Zh} \mathrm{u} \mathrm{M.-Y.,} \mathrm{Ch}$ e $\mathrm{n}$ H. Alluminium-induced cell death in root-tip cells of barley. Environ. Exp. Bot., 2001, 46: 71-79.

8. M u r z a e v a S.V. Prikladnaya biokhimiya i mikrobiologiya, 2004, 40(1): 114-119.

9. G u ral' c h u k Zh.Z. Fiziologiya i biokhimiya kul'turnykh rastenii, 1994, 26(2): 107-117.

10. Fenik S.I., Trofimyak T.B., B 1 y u m Ya.B. Uspekhi sovremennoi biologii, 1995, 115(3): 261-276.

11. Kopittke P.M., Asher C.J., Kopittke R.A., Menzies N.W. Toxic effects of $\mathrm{Pb}^{2+}$ on growth of cowpea (Vigna inguiculata). Environ. Pollut., 2007, 150: 280-287.

12. S e r e g i n I.V., I v a n o v V.B. Fiziologiya rastenii, 2001, 48(4): 606-630.

13. Vassilev A., Tsonev T., Yordanov I. Physiological response of barley plants to cadmium contamination in soil during ontogenesis. Environ. Pollut., 1998, 103: 287-293 (doi: 10.1016/S0269-7491(98)00110-9).

14. Semena sel'skokhozyaistvennykh kul'tur. Metody opredeleniya kachestva /Pod redaktsiei T.I. Vasilenko [Crop seeds: estimation of quality parameters. T.I. Vasilenko (ed.)]. Moscow, 1991.

15. N e fe d'e va E.E. Fiziologo-biokhimicheskie protsessy i morfogenez u rastenii posle deistviya impul'snogo davleniya na semena. Doktorskaya dissertatsiya [Physiological, biochemical processes, and morphogenesis in plants from seeds undergone the pulse pressure. DSc Thesis]. Moscow, 2011.

16. K o $1 \mathrm{~m}$ og o r o v A.N. Confidence limits for an unknown distribution function. $A M S, 1941,12$ : 461-463.

17. S m i r n ov N.V. Uspekhi matematicheskikh nauk, 1944, 10: 179-206.

18. B e s s m e r t n y i B.S. Matematicheskaya statistika $v$ klinicheskoi, profilakticheskoi i eksperimental'noi meditsine [Mathematical statistics in clinical, prophylactic and experimental medicine]. Moscow, 1967.

19. Soudek P., Katrusakova A., Sedlacek L., Tomaszewska B., Berden$\mathrm{Zrim} \mathrm{me} \mathrm{c} \mathrm{M.} \mathrm{Effect} \mathrm{of} \mathrm{heavy} \mathrm{metals} \mathrm{on} \mathrm{inhibition} \mathrm{of} \mathrm{root} \mathrm{elongation} \mathrm{in} 23$ cultivars of flax (Linum usitatissimum L.). Arch. Environ. Contam. Toxicol., 2010, 59: 194-203.

20. Tala nova V.V., Titov A.F., B o e va N.P. Fiziologiya i biokhimiya kul'turnykh rastenii, 2001, 33(1): 33-37.

21. Korneev N.A., Sarapul'tsev B.I., Morgunova E.A. et al. Radiobiologiya, 1985, 
25(6): 768-773.

22. B a k e r A.J.M. Metal tolerance. New Phytol., 1987, 106: 93-111.

23. Ale k s e va-P o p ov a N.V. Toksicheskoe deistvie svintsa na vysshie rasteniya [Toxic effect of lead to higher plants]. Leningrad, 1991.

24. More 1 J.L., M e n c h M., Guckert A. Measurement of $\mathrm{Pb}, \mathrm{Cu}$ and $\mathrm{Cd}$ binding with mucilage exudates from maize (Zea mays L.) roots. Biol. Fertil. Soils, 1986, 2: 29-34.

25. S e r e g i n I.V., I v a n o v V.B. Fiziologiya rastenii, 1997, 44: 922-925.

26. Pole s s k y a O.G. Rastitel'naya kletka i aktivnye formy kisloroda [Plant cell and the active forms of oxygen]. Moscow, 2007.

27. Vodnik D., Jentschke G., Fritz E., Denayer F.-O., Degen G.H. Root-applied cytokinin reduces lead uptake and affects its distribution in Norway spruce seedlings. Physiol. Plant, 1999, 106: 75-81 (doi: 10.1034/j.1399-3054.1999.106111.x).

28. Coughtrey P.J., Martin M.H. Cadmium uptake and distribution in tolerant and nontolerant population of Holcus lanatus grown in solution culture. Oicos, 1978, 30: 555-560.

29. Rudak ova E.V., Karakis K.D., S i dorshina E.I. Fiziologiya i biokhimiya kul'turnykh rastenii, 1988, 20: 3-12.

30. O u a rity O., B ous sa m a N. Cadmium and copper-induced changes in tomato membrane lipids. Phytochemistry, 1997, 45: 1343-1350 (doi: 10.1016/S0031-9422(97)00159-3.

31. Qureshi J.A., Hardwick K., Collin H.A. Intracellular localization of lead in a lead tolerant and sensitive clone of Anthoxantum odoratum. J. Plant. Physiol., 1986, 122: 357-364 (doi: 10.1016/S0176-1617(86)80168-7).

32. Resse R.N., Roberts L.M. Effects of cadmium on whole cell and mitochondrial respiration in tobacco cells suspension cultures. J. Plant. Physiol., 1985, 120: 123-130.

33. Maldiney E., Thouve n in S. De l'influence des rayons X sur la germination. Revue gen. de Botanique, 1898, 10: 81-86.

34. Ev l1 e r E. Uber die heilende Wirkung der Rontgenstrahlen bei abgegrentzen Eiterungen. Veroffentl. Geb. Des Militar. Sanitatswesens. Berlin. Jahrb. D. Wissensch. Botanik, 1906, 56: 416.

35. Van Assche F., Glijsters H. Effects of metals on enzyme activity in plants. Plant Cell Environ., 1990, 13: 195-206.

36. Schreiber L., Hartmann K. Apoplastic barriers in roots: chemical composition of endodermal and hypodermal cell walls. J. Exp. Bot., 1999, 50: 1267-1280 (doi: $10.1093 / \mathrm{jxb} / 50.337 .1267)$.

37. B r e c k le S.W. Growth under stress: heavy metals. NY, 1991.

38. S a $1 \mathrm{t}$ D.E., R a u s e $\mathrm{r}$ W.E. Mg-ATP-Dependent transport of phytochelatins across the tonoplast of oat roots. Plant. Physiol., 1995, 107: 1291-1301.

39. Antosi e witz D.M. Adaptation of plants to the environmental pollution with heavy metals. Acta Soc. Bot. Pollon., 1992, 61: 281-299.

40. Cutle r J.M., Rains D.M. Characterization of cadmium uptake by plant tissue. Plant Physiol., 1974, 54: 67-71.

41. K u m a r P.B.A.N. Phytoextraction: the use of plants to remove heavy metals from soil. Environ. Sci. Technol., 1995, 29: 1232-1238 (doi: 10.1021/es00005a014).

42. McGrath S.P. Heavy metal uptake and chemical changes in the rhizosphere of Thlaspi caerulescens growth in contaminated soils. Plant and Soil, 1997, 188: 153-159.

43. W i e r z b i c k a M. Lead translocation and localization in Allium cepa roots. Can. J. Bot., 1987, 65: $1851-1860$.

44. Zhuikova T.V., Pozolot in a V.N., B e ze l' V.S. Ekologiya, 1999, 3: 189-196.

45. Titov A.F., Laidine $\mathrm{n}$ G.F., Kaznina N.M. Fiziologiya i biokhimiya kulturnykh rastenii, 2001, 33(5): 387-384.

46. S a rapul'tse v B.I., Ge ras'kin S.A. Geneticheskie osnovy radiorezistentnosti $i$ evolyutsii [Genetic bases of radiotolerance and evolution]. Moscow, 1993.

47. D i n e va S.B., A b r a mov V.I., $\mathrm{S}$ h e v c h e $\mathrm{nko}$ V.A. Radiatsionnaya biologiya. Radioekologiya, 1994, 34(2): 177-181.

48. L y s e nko E.A., Ka l' che nko V.A., Shevche nko V.A. Radiatsionnaya biologiya. Radioekologiya, 1999, 39(6): 623-629.

49. Kal'chenko V.A., Shevehenko V.A., Fedotov I.S. Genetika, 1981, 17(1): 137-141.

50. Broadley M.R., Willey N.J., Wilk ins J.C., Newton A.C., E 11 is R.P., This D. Phylogenetic variation in heavy metal accumulation in angiosperms. New Phytol., 2001, 152: 1-19 (doi: 10.1046/j.0028-646x.2001.00238.x). 